\title{
Kinerja KPU Kota Blitar Dalam Meningkatkan Partisipasi Pemilih Pada Pemilihan Gubernur Dan Wakil Gubernur Jawa Timur Tahun 2018
}

\author{
Pristiko Gunawan \\ Magister Manajemen Universitas Islam Kadiri
}

\begin{abstract}
The direct election of the Governor and Deputy Governor is the implementation of the mandate of the law, this study has the aim to determine the extent of the performance of the KPU Blitar City in increasing voter participation in the election of the Governor and Deputy Governor of East Java in 2018. There are various problems which includehuman resources from KPU has not been optimal in the level of village government and sub-district government, and lack of participation from the community due to factors of economic interests, domiciles in the outer areas of Blitar City, and lack of public awareness. The performance theory proposed by Mahsun (2012: 77) is used as a theoretical basis. The object of the research was the Blitar City KPU, carried out through a qualitative approach using interview methods and using secondary data in the form of literature studies from several scientific references suitable for following up the analysis of primary data obtained. The results of the study illustrate that the performance of the Blitar City KPU in the election of the Governor and Deputy Governor of East Java in 2018 cannot be said to be optimal. Because there are still obstacles to the Blitar City Election Commission in increasing voter participation which is seen from the indicators of input, process, results and impact.

Keywords: Performance, Voter Participation, Democracy
\end{abstract}

\section{Latar belakang teoretis.}

Penyelenggaraan Pemilihan Umum Gubernur Jawa Timur yang dilaksanakan tanggal 27 Juni 2018, merupakanpenerapan dari Undang-Undang Nomor 8 Tahun 2015tentang Perubahan Atas UndangUndang Nomor 1 Tahun 2015 tentang Penetapan Peraturan Pemerintah Pengganti Undang-Undang Nomor 1 Tahun 2014 tentang Pemilihan Gubernur, Walikota, dan Walikota menjadi Undang-Undang.

BerdasarkanUndang-Undang Nomor 23 Tahun 2014 tentang Pemerintahan Daerah pasal 1 ayat (2), definisi pemerintahan daerah adalah:

Pemerintahan Daerah adalah penyelenggaraan urusanpemerintahan oleh pemerintah daerah dan dewan perwakilan rakyat daerah menurut asas otonomi dan tugas pembantuan dengan prinsip otonomi seluas-luasnya dalamsistem dan prinsip Negara Kesatuan Republik Indonesiasebagaimana dimaksud dalam Undang-Undang Dasar Negara Republik Indonesia Tahun 1945.

Amirullah (2018:210) menyebutkan bahwa kinerja pada dasarnya merupakan hasil kerja secara kualitas dan kuantitas yang dicapai seorang pegawai dalam melaksanakan tugasnya sesuai tanggung jawab yang diberikan kepadanya.

$$
\text { Mahsun (2012:77) berpendapat }
$$

bahwa ada beberapa jenis indikator kinerja instansi pemerintahan yaitu:

1. Indikator Masukan (input)

Segala sesuatu yang dibutuhkan agar pelaksanaan kegiatan dapat berjalan untuk menghasilkan keluaran. Indikator ini mengukur sumber daya seperti anggaran (dana), sumber daya manusia, peralatan, material, dan masukan lain yang dipergunakan untuk melaksanakan kegiatan. Dengan meninjau distribusi sumber daya, suatu lembaga dapat menganalisis apakah alokasi sumber daya yang dimiliki telah sesuai dengan rencana strategis yang ditetapkan.Tolok ukur ini dapat pula digunakan untuk perbandingan (benchmarking) dengan lembaga-lembaga relevan.

2. Indikator Proses (process)

Organisasi merumuskan ukuran kegiatan, baik dari segi kecepatan, ketepatan, maupun tingkat akurasi pelaksanaan kegiatan tersebut.Rambu yang paling dominan dalam proses adalah tingkat efisiensi dan ekonomis pelaksanaan kegiatan organisasi. Efisiensi berarti banyaknya hasil yang diperoleh dengan 
pemanfaatan sejumlah input. Sedangkan yang dimaksud dengan ekonomis adalah bahwa suatu kegiatan yang dilaksanakan lebih murah dibandingkan dengan standar biaya atau waktu yang telah ditentukan untuk itu.

3. Indikator Keluaran (output)

Sesuatu yang diharapkan langsung dapat dicapai dari suatu kegiatan yang dapat berupa fisik dan nonfisik.Indikator atau tolok ukur mengukur keluaran yang dihasilkan dari suatu kegiatan.Dengan membandingkan keluaran, instansi dapat menganalisis apakah kegiatan telah dilaksanakan sesuai dengan rencana.

4. Indikator Hasil (outcomes)

Segala sesuatu yang mencerminkan berfungsinya keluaran kegiatan pada jangka menengah (efek langsung).Pengukuran indikator hasil seringkali rancu dengan indikator keluaran.Indikator outcome lebih utama dari sekedar output.Walaupun produk telah berhasil dicapai dengan baik, belum tentu outcome kegiatan tersebut telah tercapai.Outcome menggambarkan tingkat pencapaian atas hasil yang lebih tinggi yang mungkin mencakup kepentingan banyak pihak.Dengan indikator outcome, organisasi akan dapat mengetahui apakah hasil yang telah diperoleh dalam bentuk output memang dapat dipergunakan sebagaimana mestinya dan memberikan kegunaan yang besar bagi masyarakat banyak.

5. Indikator Manfaat (benefit)

Sesuatu yang berkaitan dengan tujuan akhir dari pelaksanaan kegiatan.Indikator manfaat menggambarkan manfaat yang diperoleh dari indikator hasil.Manfaat tersebut baru tampak setelah beberapa waktu kemudian, khususnya dalam jangka menengah dan panjang.Indikator manfaat menunjukkan hal yang diharapkan dapat diselesaikan dan berfungsi dengan optimal (tepat lokasi dan waktu).

6. Indikator Dampak (impact)

Pengaruh yang ditimbulkan baik positif maupun negatif.

Berdasarkan pendapat diatas indikator kinerja diperlukan sebagai ukuran kuantitatif dan/atau kualitatif yang menggambarkan tingkat pencapaian suatu sasaran atau tujuan yang telah ditetapkan. Ketidakjelasan indikator kinerja, akan mengakibatkan kesulitan dalam mengukur atau menilai kinerja.

Tingkat partisipasi oleh Arnstein dalam Karianga (2011:244), ada tiga derajat partisipasi pemilih, yaitu:

1. Tidak partisipasif (nomparticipation);

2. Derajat semu (degrees of tokenism); dan

3. Kekuatan masyarakat (degrees of citizen power).

Partisipasi pemilih menurut Adi (2007:27) adalah "keikutsertaan masyarakat dalam proses pengidentifikasian masalah dan potensi yang ada di masyarakat, pemilihan dan pengambilan keputusan tentang alternatif solusi untuk menangani masalah, pelaksanaan upaya mengatasi masalah, dan keterlibatan masyarakat dalam proses mengevaluasi perubahan yang terjadi."

Dari beberapa pendapat ahli di atas dapat disimpulkan bahwa partisipasi pemilih merupakan peranan dari masyarakat dalam menyikapi seluruh proses kegiatan atau masalah dengan menyumbangkan baik pikiran, tenaga maupun materi baik secara sukarela ataupun paksaan.

Masyarakat Kota Blitar cenderung bersikap apatis terhadap pemerintahan yang ada, hal ini menyebabkan adanya ketidak mau tahuan masyarakat dalam hal Pemilihan secara langsung tersebut, faktor lain yaitu belum tingginya kesadaran masyarakat dalam proses pemilihan langsung oleh masyarakat ini yang seharusnya mendapatkan respon yang baik.Terdapat beberapa masyarakat yang lebih memilihpergi ke ladang dan pasar untuk bekerja atau malah pergi untuk berlibur memanfaatkan tanggadaripada pergi ke TPS untuk memilih kepala daerah. Selain itu, banyak penduduk Kota Blitar yang berada di luar wilayah Kota Blitar karena mnempuh pendidikan atau pekerjaan seperti menjadi Tenaga Kerja Indonesia baik yang bekerja di luar pulau atau di luar negeri.

Pemilihan Gubernur dan Wakil Gubernur Jawa Timur diselenggarakan oleh Komisi Pemilihan Umum. Komisi Pemilihan Umum (KPU) merupakan lembaga Negara yang menyelenggarakan pemilihan umum di Indonesia, yakin meliputi Pemilihan Umum Anggota DPR, DPD, DPRD, Pemilihan Umum Presiden dan Wakil Presiden, serta Pemilihan Umum Kepala Daerah dan Wakil 
Kepala Daerah. Sebelum Pemilu 2004, KPU dapat terdiri dari anggota-anggota yang merupakan anggota sebuah partai politik, namun setelah dikeluarkannya UndangUndang Nomor 4 Tahun 2000, maka diharuskan bahwa KPU adalah non-partisan.

Merujuk pada latar belakang masalah di atas dengan beberapamasalah yang ada,maka penulis tertarik untuk melakukan penelitian yang dituangkan dalamJurnal dengan judul yaitu"Kinerja Kpu Kota Blitar Dalam Meningkatkan Partisipasi Pemilih Pada Pemilihan Gubernur Dan Wakil Gubernur Jawa Timur Tahun 2018"

\section{Metode Penelitian}

Desain Penelitian

$$
\text { Menurut Moleong (2010:6) }
$$

menyatakan bahwa "penelitian kualitatif penelitian yang bermaksud untuk memahami fenomena tentang apa yang dialami oleh subjek penelitian, misalnya perilaku, persepsi, tindakan dan lain-lain."

Penulismenggunakan metode deskriptifyaitu penulismencari pemahamanmakna berdasarkan fakta yang ada di lapangan, kemudian menelaah supaya diperoleh gambaran yang jelas dan sistematis dalam pemecahan masalah yang ada. Peneliti melakukannya dengan cara menggambarkan, menjelaskan kemudian menyusun hasil suatu kondisi secara teratur sesuai dengan fakta dari suatu fenomena yang dihubungkan dengan teori yang ada agar kemudian bisa ditarik kesimpulan sebagai upaya dalam pemecahan masalah. Tujuan dari penelitian ini adalah untuk membuat deskripsi, gambaran secara sistematis, berdasarkan fakta dan akurat terhadap fakta-fakta, sifat-sifat serta hubungan antar fenomena yang diteliti.

Penelitian ini bertujuan untuk mengetahui dan menganalisis bagaimana kinerja KPU Kota Blitar dalam meningkatkan partisipasi pemilih pada Pemilihan Gubernur dan Wakil Gubernur Jawa Timur Tahun 2018. Dengan demikian maka penelitian ini mendeskripsikan berbagai kondisi termasuk yang didalamnya berupa kondisi geografis, kondisi demografis terutama jumlah penduduk, pendidikan, sosial ekonomi, sarana dan prasarana, instansi penelitian, dan indikator kinerja, sehingga dapat diketahui peningkatan partisipasi pemilihnya.

\subsection{Sumber Data}

Menurut Arikunto (2010:172) mengklasifikasikan sumber data dimaksud menjadi tiga, yaitu person (orang), paper (kertas/dokumen), dan place (tempat) yang digunakan sebagai berikut:

1. Person (orang)

Merupakan sumber data yang bisa memberikan data berupa jawaban lisan melalui wawancara atau jawaban tertulis melalui angket. Orang juga merupakan tempat penulis bertanya mengenai permasalahan yang sedang diteliti. Oleh karena itu sumber data ini adalah berupa orang per orang yang dapat dijadikan sumber penelitian melalui wawancara dengan informan yaitu pihak-pihak yang penulis jadikan narasumber dalam penelitian ini.

2. Paper (kertas/dokumen)

Adalah sumber data yang menyajikan tanda-tanda berupa huruf, tabeltabel, gambar atau simbol-simbol lain. Dengan pengertian ini maka "paper" dalam bahasa Inggris, tetapi dapat berwujud batu, kayu tulang, daun lontar dan sebagainya, yang cocok untuk penggunaan metode dokumentasi.

3. Place (tempat)

Adalah sumber data yang menyajikan tampilan dalam keadaan diam dan bergerak. Diam misalnya ruangan, kelengkapan alat, wujud benda, warna dan lain-lain. Bergerak misalnya aktifitas kinerja, laju dan lain sebagainya.

Informan / Responden dan Cara
$\begin{gathered}\text { Menentukannya } \\ \text { Berhubung penelitian }\end{gathered}$ menggunakan metode penelitian deskriptif kualitatif, maka secara teori, penulis tidak menggunakan populasi dan sampel. Menurut Arikunto (2010:13) menyatakan bahwa "Penelitian kualitatif tidak menggunakan pendekatan populasi dan sampel. Dengan kata lain, dalam penelitian kualitatif tidak dikenal istilah populasi dan sampel. Istilah yang digunakan adalah setting." Hasil penelitian hanya berlaku bagi setting yang bersangkutan.

Oleh karena itu, dalam metode penelitian deskriptif kualitatif ini, penulis hanya menggunakan informan saja. 
Berdasarkan definisi informan di atas maka penulis menetapkan bahwa yang menjadi informan dalam penelitian ini sebagai berikut:

Tabel 3.1

Daftar Informan

\begin{tabular}{|c|c|c|c|}
\hline $\begin{array}{l}\mathbf{N} \\
\mathbf{o}\end{array}$ & $\begin{array}{l}\text { Sumber } \\
\text { informan }\end{array}$ & Jumlah & Keterangan \\
\hline 1 & 2 & 3 & 4 \\
\hline 1 & Policy Maker & 1 orang & $\begin{array}{l}\text { Ketua KPU Kota } \\
\text { Blitar }\end{array}$ \\
\hline 2 & Implementor & $\begin{array}{l}1 \text { orang } \\
4 \text { orang } \\
4 \text { orang }\end{array}$ & $\begin{array}{l}\text { - Sekretaris KPU } \\
\text { Kota Blitar } \\
\text { - Divisi KPU Kota } \\
\text { Blitar } \\
\text { - Kepala Sub Bagian } \\
\text { Sekretariat KPU } \\
\text { Kota Blitar }\end{array}$ \\
\hline \multirow[t]{4}{*}{3} & \multirow[t]{4}{*}{ Target Grup } & \multirow{4}{*}{$\begin{array}{l}2 \text { orang } \\
2 \text { orang } \\
2 \text { orang } \\
4 \text { orang }\end{array}$} & $\begin{array}{l}\text { - PPK (Panitia } \\
\text { Pemilihan } \\
\text { Kecamatan) }\end{array}$ \\
\hline & & & $\begin{array}{l}\text { - PPS (Panitia } \\
\text { Pemungutan Suara) }\end{array}$ \\
\hline & & & $\begin{array}{l}\text { - KPPS (Kelompok } \\
\text { Penyelenggara } \\
\text { Pemungutan Suara) }\end{array}$ \\
\hline & & & $\begin{array}{l}\text { - DPT (Daftar } \\
\text { Pemilih Tetap) }\end{array}$ \\
\hline & Jumlah & 20 orang & \\
\hline
\end{tabular}

Teknik dan Instrumen Pengumpulan Data

Dalam penelitian ini penelitian ini penulis menggunakan metode wawancara, maka instrumennya adalah pedoman wawancara dengan menggunakan pedoman wawancara sebagai instrumennya maka penulis melakukan wawancara serta pencatatan terhadap data yang diperlukan terkait kinerja KPU Kota Blitar dalam meningkatkan partisipasi pemilih pada Pemilihan Gubernur dan Wakil Gubernur Jawa Timur Tahun 2018.

\section{Teknik Analisis}

Sugiono (2013:335) "Analisis data kualitatif adalah bersifat induktif, yaitu suatu analisi berdasarkan data yag diperoleh, selanjutnya dikembangkan pola hubungan tertentu atau menjadi hipotesis." Langkahlangkah yang dilakukan dalam menganalisis data menurut model Miles and Huberman dalam Sugiyono (2013:337), mengemukakan bahwa aktivitas dalam analisis data, yaitu data reduction, data display, dan data conclusion drawing/verification.

Adapun tahapan analisisnya yaitu pertama data yang diperoleh dari hasil dokumentasi,wawancara dan observasi langsung dianalisis dan interpestasi data dilakukan pada waktu penelitian sedang berlangsung maupun semua data yang diperlukan pada waktu penelitian sedang berlangsung maupun setelah semua data yang diperlukan terkumpul dan disimpan di dalam dokumen. Selama proses penelitian berlangsung, penulis selalu memperhatikan dan menganalisis terhadap data baru yang diperoleh dalam proses penyajian data, apabila terlihat data yang kurang relevan dilakukan reduksi data untuk memudahkan proses analisis data agar melakukan penarikan kesimpulan sesuai dengan tujuan penelitian. Setiap proses analisis data saling berhubungan dan senantiasa dilakukan dalam waktu bersamaan.

Artinya hasil data yang telah diperoleh dilapangan melalui instrument angket selanjutnya diolah dengan menggunakan tabulasi data atas jawaban yang diberikan oleh respon dalam hal ini pegawai di KPU Kota Blitar melalui proses penyelesaian pekerjaan, kemudian dianalisis dengan menggunakan teknik analisis deskriptif yaitu menguraikan gambaran tentang tingkat partisipasi pemilih berdasarkan kinerja KPU Kota Blitar sesuai dengan tujuan penelitian ini.

\section{hasil Penelitian}

\section{Hasil Penelitian dan Pembahasan}

Salah satu indikator keberhasilan dari proses kinerja adalah meningkatnya Partisipasi Pemilih, karena dalam aspek pelayanan publik suatu organisasi, masyarakat merupakan sasaran utama dalam kinerja organisasi. Dalam pelaksanaan kinerja tersebut diperlukan indikator-indikator agar terlihat pencapaian kinerja organisasi dalam hal ini adalah KPU Kota Blitar.

Berdasarkan kajian teoritis yang telah penulis uraikan yakni menurut Mahsun (2012:77), hasil wawancara penulis dengan narasumber, dan melalui data yang didapat, maka indikator-indikator kinerja KPU dalam 
meningkatkan Partisipasi Pemilih adalah sebagai berikut:

\section{Indikator Masukan (input)}

Indikator ini mengukur sumber daya seperti anggaran (dana), sumber daya manusia, peralatan, material, dan masukan lain, yang dipergunakan untuk melaksanakan kegiatan. Dengan meninjau distribusi sumber daya, KPU Kota Blitar dapat menganalisis apakah alokasi sumber daya yang dimiliki telah sesuai dengan rencana strategis yang ditetapkan.

Berdasarkan data yang penulis dapatkan melalui penelitian, kinerja KPU Kota Blitar yang diukur melalui indikator kinerja dari segi masukan (input) oleh pendapat Mahsun (2012:77) disimpulkan belum optimal, karena SDM anggota Badan Penyelenggara KPU dalam pendidikan masih kurang. Hal ini tidak sesuai dengan pendapat Dessler (2010:329) tentang penilaian kinerja melalui indikator pengetahuan mengenai pekerjaan yakni keahlian praktis dan teknik dan informasi yang digunakan pekerjaan. Selain itu, berdasarkan pendapat Mahmudi (2010:20) faktor-faktor yang mempengaruhi kinerja diantaranya faktor personal/individu yang meliputi pengetahuan, keterampilan/skill, kemampuan, kepercayaan diri, motivasi, dan komitmen yang dimiliki setiap individu, sehingga SDM berpengaruh terhadap kinerja KPU pada tahapan Pemilihan Gubernur dan Wakil Gubernur Jawa Timur disamping anggaran dan sarana dan prasarana. Apabila satu diantaranya tidak terpenuhi, maka tidak akan dapat dilaksanakannya Pemilihan Gubernur dan Wakil Gubernur Jawa Timur tersebut.

\section{Indikator Proses (process)}

Kegiatan dalam Pemilihan Gubernur dan Wakil Gubernur Jawa Timur antara lain sosialisasi, pembentukan Badan Penyelenggara, pemutakhiran DPT, pencalonan, kampanye, pemungutan dan penghitungan suara serta penetapan calon terpilih dan pelantikan.

Berdasarkan data yang penulis dapatkan melalui penelitian, kinerja KPU Kota Blitar yang diukur melalui indikator kinerja dari segi proses (process) oleh pendapat Mahsun (2012:77) disimpulkan belum optimal, karena pelaksanaan rangkaian kegiatan Pemilihan Gubernur dan Wakil Gubernur Jawa Timur belum mencapai sasaran yang tepat dari segi sosialisasi maupun pelaksanaan kegiatan yang lain. Hal ini tidak sesuai dengan pendapat Sedarmayanti (2011:196-197) bahwa kinerja organisasi diukur dari aspek diantaranya operasi bisnis internal untuk memastikan bahwa seluruh kegiatan organisasi sudah seirama untuk mencapai tujuan dan sasaran organisasi seperti yang tercantum dalam recana strategis serta untuk melakukan perbaikan terus menerus atas efisiensi dan efektivitas operasi organisasi.

\section{Indikator Keluaran (output)}

Hasil observasi dan wawancara yang diperkuat dengan studi dokumentasi yang telah dilakukan saat penelitian. Berdasarkan data yang penulis dapatkan melalui penelitian, kinerja KPU Kota Blitar yang diukur melalui indikator kinerja dari segi keluaran (output) oleh pendapat Mahsun (2012:77) disimpulkan baik dan sistematis secara administrasi dan kegiatan yang dilaksanakan teratur.

\section{Indikator Hasil (outcomes)}

Hasil kegiatan Pemilihan Gubernur dan Wakil Gubernur Jawa Timur Kota Blitar dapat dilihat sebagai segala sesuatu yang mencerminkan berfungsinya Keputusan KPU Kota Blitar pada jangka menengah (efek langsung).

Hasil observasi mengemukakan bahwa dalam hal ini masyarakat terbagi menjadi dua kelompok tingkat partisipasi yang termasuk dalam pendapat Pretty J. dalam Karianga (2011:223), yakni tingkat partisipasi pasif dan manipulatif dan tingkat partisipasi intensif. Karakteristik masyarakat dengan tingkat partisipasi pasif dan manipulatif ini dialami oleh kalangan DPT Pemilihan Gubernur dan Wakil Gubernur Jawa Timur Tahun 2018. Karakteristik masyarakat dengan tingkat partisipasi intensif ini dialami oleh anggota Badan Penyelenggara KPU Kota Blitar, dimana masyarakat memberi pengorbanan dan jasa untuk memperoleh imbalan insentif berupa upah, walau tidak dilibatkan dalam proses pembelajaran atau eksperimen-eksperimen yang dilakukan karena telah dilaksanakan oleh Anggota KPU dan Sekretariat KPU, dan selanjutnya tidak memiliki andil untuk melanjutkan kegiatan setelah insentif dihentikan. 


\section{Indikator Manfaat (benefit)}

Berkaitan dengan tujuan akhir pelaksanaan Pemilihan Gubernur dan Wakil Gubernur Jawa Timur Tahun 2018, manfaat yang diperoleh berdasarkan hasil Pemilihan Gubernur dan Wakil Gubernur Jawa Timur yang didapat, diantaranya akan dinikmati oleh masyarakat dan organisasi.

Berdasarkan data yang penulis dapatkan melalui penelitian, kinerja KPU Kota Blitar yang diukur melalui indikator kinerja dari segi manfaat (benefit) oleh pendapat Mahsun (2012:77) disimpulkan kegiatan Pemilihan Gubernur dan Wakil Gubernur Jawa Timur bermanfaat untuk organisasi dan masyarakat dalam jangka waktu menengah, namun belum didapatkan manfaat yang diterima pada jangka panjang

\section{Indikator Dampak (impact)}

Dampak diselenggarakannya pemilihan gubernur dan wakil gubernur Jawa Timur Tahun 2018 secara umum dapat diukur melalui dirasakan oleh masyarakat sebagai obyek pelaksanaan Pemilihan Gubernur dan Wakil Gubernur Jawa Timur.

Berdasarkan data yang penulis dapatkan melalui penelitian, kinerja KPU Kota Blitar yang diukur melalui indikator kinerja dari segi dampak (impact) oleh pendapat Mahsun (2012:77) disimpulkan adanya dampak negatif terkait dengan pendapatan sehari-hari karena harus meninggalkan pekerjaan yang diterima oleh masyarakat. Hal ini tidak sesuai dengan pendapat Bernadin dalam Sudarmanto (2009:12) yang menyampaikan bahwa dimensi untuk mengukur kinerja diantaranya interpersonal impact yakni kemampuan individu dalam meningkatkan perasaan harga diri, keinginan baik dan kerjasama diantara sesama masyarakat.

\section{Kesimpulan}

Kinerja KPU dalam meningkatkan partisipasi masyarakat pada Pemilihan Gubernur dan Wakil Gubernur Provinsi Jawa Timur Tahun 2018 belum sepenuhnya optimal, hal ini dapat terlihat dari indikator kinerja sebagai berikut:

a. Indikator masukan (input), belum optimal.

b. Indikator proses (process), belum optimal c. Indikator keluaran (output), sudah optimal.

d. Indikator hasil (outcome), belum optimal

e. Indikator manfaat (benefit), sudah optimal

f. Indikator dampak (impact), sudah optimal

\section{Rekomendasi}

Penulis mengemukakan beberapa saran yakni KPU Kota Blitar dalam mengatasi masalah pada kinerja KPU Kota Blitar, antara lain:

a. KPU Kota Blitar lebih intens dalam mengadakan pelatihan-pelatihan teknis maupun fungsional yang sifatnya menyeluruh di masingmasing kecamatan

b. KPU Kota Blitar perlu mengadakan perekrutan anggota Badan Penyelenggara secara transparan dengan memberikan gambaran reward untuk menarik minat

c. KPU Kota Blitar perlu mengemas lebih menarik pada kegiatan sosialisasi dan disesuaikan dengan karakteristik masyarakat, misalnya melalui kesenian Ludruk, Wayang, dan sebagainya.

d. Pelaksanaan Focus Group Discussion yang melibatkan masyarakat dari segala unsur, sehingga mampu mengakomodir permasalahan yang muncul dan menemukan solusi yang dapat diterima dan dilaksanakan oleh masyarakat secara menyeluruh.

e. Evaluasi terhadap program kerja yang disusun oleh KPU Kota Blitar pada setiap tahapan pemilihan umum, baik itu Pemilihan Presiden, Pemilihan Gubernur dan Wakil Gubernur, Pemilihan Bupati dan Wakil Bupati, dan Pemilihan Legislatif.

\section{Daftar Pustaka}

Adi, Isbandi, R. 2007. Perencanaan Partispatoris Berbasis Aset Komunitas (dari Pemikiran Menuju Penerapan). Jakarta, FISIP UI Press.

Amirullah. 2015. Manajemen Strategi: TeoriKonsep-Kinerja. Jakarta, Mitra Wacana Media. 
Arikunto, Suharsimi. 2010. Prosedur Penelitian Suatu Pendekatan Praktik. Jakarta, Rineka cipta.

Dessler, Gary. 2010. Manajemen Sumber Daya Manusia, Penerjemah: Eli Tanya. Jakarta, Index.

Karianga, Hendra. 2011. Partisipasi Masyarakat Dalam Mengelola Keuangan Daerah (Perspektif Hukum dan Demokrasi). Bandung, PT. Alumni.

Mahmudi, 2010. Manajemen Kinerja Sektor Publik. Sekolah Tinggi Ilmu Manajemen YKPN.

Mahsun, Mohammad. 2012, Pengukuran Kinerja Sektor Publik. Yogyakarta, BPFE Yogyakarta.

Moleong, Lexy J. 2012. Metode Penelitian Kualitatif. Bandung, Remaja Rosdakarya.

Sedarmayanti. 2011. Manajemen Sumber Daya Manusia: Reformasi Birokrasi dan Manajemen Pegawai Negeri Sipil. Bandung, Refika Aditama.

Sudarmanto. 2009. Kinerja dan Pengembangan Kompetensi. Yogyakarta, Pustaka Belajar.

Sugiyono. 2013. Metode Pendidikan Penelitian. Bandung, Alfabeta.

\section{Peraturan Perundang-Undangan}

1. Undang-Undang Nomor 23 Tahun 2014 tentang Pemerintahan Daerah

2. Undang-Undang Nomor 8 Tahun 2015 tentang Perubahan Atas Undang-Undang Nomor 1 Tahun 2015 tentang Penetapan Peraturan Pemerintah Pengganti UndangUndang Nomor 1 Tahun 2014 tentang Pemilihan Gubernur, Bupati, dan Walikota Menjadi UndangUndang 